\title{
Associations between the HLA-A polymorphism and the clinical manifestations of Behcet's disease
}

\author{
Eun Ha Kang ${ }^{1 \dagger}$, Jeong Yeon Kim² ${ }^{\dagger}$, Fujio Takeuchi ${ }^{3}$, Joon Wan Kim² ${ }^{2}$ Kichul Shin² ${ }^{2}$ Eun Young Lee ${ }^{2}$, Yun Jong Lee , \\ Eun Bong Lee ${ }^{2,4}$, Myoung Hee Park ${ }^{4,5}$ and Yeong Wook Song ${ }^{2,4^{*}}$
}

\begin{abstract}
Introduction: The objective was to investigate associations between the HLA-A gene and Behcet's disease (BD) and its clinical manifestations.

Methods: Genotyping for the HLA-A locus was performed using the polymerase chain reaction-Luminex typing method in $223 \mathrm{BD}$ patients and 1,398 healthy controls.

Results: The phenotypic frequencies of HLA-A*02:07 (odds ratio $(\mathrm{OR})=2.03, P=0.002), A^{*} 26: 01$ (OR $=1.85$, $P=0.008)$, and $A^{*} 30: 04(\mathrm{OR}=2.51, P=0.006)$ tended to be higher in $\mathrm{BD}$ patients than in normal controls, but the frequency of $A^{*} 33: 03(\mathrm{OR}=0.59, P=0.003)$ tended to be lower in $\mathrm{BD}$ patients. A meta-analysis adopting our and the Japanese data confirmed the associations of $H L A-A^{*} 02: 07, A^{*} 26: 01$, and $A^{*} 33: 03$ with BD. Furthermore, the frequencies of the $H L A-A^{*} 02: 07, A^{*} 26: 01$, and $A^{*} 30: 04$ were significantly higher in patients with skin lesions $(O R=$ 2.37, $P<0.0005, P C<0.012)$ and arthritis $(\mathrm{OR}=2.32, P=0.002, P C=0.048)$, with uveitis $(\mathrm{OR}=3.01, P<0.0005, P C$ $<0.012)$, and with vascular lesions $(\mathrm{OR}=9.80, P<0.0005, P C<0.012)$ and a positive pathergy test $(\mathrm{OR}=4.10, P=$ $0.002, P C=0.048)$, respectively, than in controls. In $H L A-B^{*} 51$ non-carriers, these associations were also significant, being much stronger between HLA-A*26:01 and uveitis $(O R=4.19, P<0.0005, P C<0.012)$ and between HLA$A^{*} 30: 04$ and vascular lesions (OR $\left.=13.97, P<0.00005, P C<0.0012\right)$. In addition, HLA-A*30:04 was associated with genital ulcers in $H L A-B^{*} 51$ non-carriers $(\mathrm{OR}=3.89, P=0.002, P C=0.048)$.

Conclusions: $H L A-A^{*} 02: 07, A^{*} 26: 01$, and $A^{*} 30: 04$ were associated with increased risk for $B D$, while HLA-A*33:03 with decreased risk. HLA-A*02:07, $A^{*} 26: 01$, and $A^{*} 30: 04$ were associated with skin lesions and arthritis, with uveitis, and with vascular lesions, genital ulcers, and a positive pathergy test, respectively.
\end{abstract}

\section{Introduction}

Behcet's disease (BD) is a chronic relapsing inflammatory disease characterized by oro-genital ulcers, cutaneous inflammation, and uveitis. In addition to its typical muco-cutaneous and ocular manifestations, BD targets the musculoskeletal, vascular, nervous, and gastrointestinal systems [1]. Although the etiology of BD remains unclear, strong familial aggregations [2,3], a geographic distribution favoring the Middle East and East Asia [4], and the known association between BD and $H L A-B * 51 \quad[4,5]$ indicate that genetic background importantly contributes to the pathogenesis of BD.

\footnotetext{
* Correspondence: ysong@snu.ac.kr

+ Contributed equally

${ }^{2}$ Division of Rheumatology, Department of Internal Medicine, Seoul National University Hospital, 28 Yeongeon-dong, Jongno-gu, Seoul, Korea Full list of author information is available at the end of the article
}

In fact, $H L A-B * 51$, the most prominent susceptibility gene $[4,5]$, has been estimated to increase the relative risk of BD by $20 \%$ in the siblings of affected individuals [6], which suggests that other susceptibility loci exist. Candidate gene analyses have added a number of other genetic susceptibility loci for BD in and out of the MHC region [7-11]. However, the associations between the genes near MHC I region and BD are often doubted because of their linkage disequilibrium with $H L A-B * 51$. On the other hand, recent genome-wide association studies (GWAS) have identified novel susceptibility loci across chromosomes [12-16] and HLA-A gene was shown to constitute a second independent susceptibility locus [14-16]. The HLA-A gene has been genotyped in BD patients with different ethnicities, and $H L A-A * 26$ was reported to be associated with BD in Taiwan, Greece, and Japan [17-19]. In addition, a significant

\section{Biomed Central}


association between the $H L A-A * 26: 01$ subtype and BD was found in Japan [14]. In the present study, we genotyped the HLA-A gene in Korean BD patients and investigated the associations between its alleles and $\mathrm{BD}$ and the clinical features of BD.

\section{Materials and methods}

\section{Patients and samples}

Two hundred and twenty-three unrelated Korean patients who met the classification criteria proposed by the International Study Group for BD [20] were consecutively enrolled at Seoul National University Hospital. Medical records were reviewed for data regarding clinical manifestations. In addition to the data on oro-genital ulcers, skin and eye lesions, we collated data on arthritis based on joint swelling and pain, vascular involvement based on imaging studies (ultrasound, contrast-enhanced computed tomography, and/or angiography), central nervous system involvement based on cerebrospinal fluid examination, brain magnetic resonance imaging, and/or encephaloelectrography, and endoscopically identified gastrointestinal ulcerations. For controls, 1,398 subjects from unrelated hematopoietic stem cell donor registry of Korean Network for Organ Sharing (KONOS) were included. The individual demographic data of these controls were not made available to conceal personal information. Peripheral blood was collected from patients and controls after obtaining informed consent. This study was approved by the Institutional Board Review of Seoul National University Hospital (\#0408-131-010) and patient consent was obtained.

\section{$H L A-A$ and $H L A-B^{*} 51$ genotyping}

Genomic DNA was extracted from peripheral blood using QIAamp blood kits (Qiagen, Valencia, CA, USA). The presence of $H L A-B * 51$ was determined using polymerase chain reaction (PCR)-sequence specific primers; after amplifying a 581 base pair DNA fragment using the sequence specific primers 5'-GCCGGAGTATTGGGACCGGAAC-3' and 5'-CGGAGCCACTCCACGCACAG-3', nested PCR was performed using the sequence specific primers 5'-CTTACCGAGAGAACCTGCGGATCG-3' and 5'-CCGTCGTAGGCGTACTGGTT-3' [21]. HLA-A polymorphisms were examined by the PCR-Luminex typing method using a WAKFlow HLA typing kit (Wakunaga, Hiroshima, Japan) [22]. Briefly, after generic PCR amplification of the $H L A-A$ region with biotinylated primers at the 5' end, the PCR amplicon was denatured and hybridized onto oligonucleotide probes immobilized on fluorescently-coded microsphere beads (Luminex, Austin, TX, USA) designed to specifically detect the nucleotide sequences of the PCR product at polymorphic sites of $H L A-A$ gene. At the same time, the biotinylated PCR product was labeled with phycoerythrin-conjugated streptavidin and immediately examined using a Luminex 200 analyzer (Luminex). Genotype determination and data analysis were performed automatically using WAKFlow Typing software. Whenever atypical hybridization patterns were observed, samples were directly sequenced.

\section{Statistical analysis}

Continuous values are presented as means \pm standard deviations. The chi-square test or Fisher's exact test was used to compare the phenotypic frequencies of $H L A-A$ alleles between patients and controls or between patients with and without certain clinical features. Statistical calculation was done using SPSS version 17.0 (SPSS Inc., Chicago, IL, USA). $P$-values of $<0.05$ were considered significant. For multiple testings that compare patients and controls, Bonferroni correction was used to obtain corrected $P$-values ( $P c$ value), and $P c$ values of $<0.05$ were considered significant. Odds ratios (ORs) with 95\% confidence intervals (CI) were estimated whenever applicable. For meta-analysis, data were pooled using Mantel-Haenszel method [23]. Betweenstudy heterogeneity was quantified using the $\mathrm{I}^{2}$ statistic [24]. The calculation was performed using RevMan software version 5.0 for Windows (Cochrane Collaboration, Oxford, UK).

\section{Results}

\section{Clinical characteristics of BD patients}

The clinical characteristics of the 223 BD patients are summarized in Table 1. Skin lesions $(n=180)$ included erythema nodosum $(n=130)$ and acneiform nodule $(n=105)$. Vascular involvement $(n=31)$ consisted of arterial pseudoaneurysm $(n=7)$, arterial stenosis $(n=1)$, valvulitis with or without aortitis $(n=3)$, and

\begin{tabular}{ll} 
Table $\mathbf{1}$ Demographic and clinical characteristics of $\mathbf{2 2 3}$ \\
BD patients \\
\hline Gender (M:F) & $110: 113$ \\
Age at diagnosis (years, mean \pm SD) & $43.1 \pm 10.0$ \\
Disease duration (years, mean \pm SD) & $12.8 \pm 9.2$ \\
Clinical manifestations & $n(\%)$ \\
Oral ulcer & $223(100)$ \\
Genital ulcer & $159(71.3)$ \\
Skin lesions & $180(80.7)$ \\
Positive pathergy test & $94 / 182(51.6)$ \\
Uveitis & $85(38.1)$ \\
Retinal vasculitis & $10(4.5)$ \\
Joint involvement & $125(56.1)$ \\
Vascular involvement & $33(14.8)$ \\
Central nervous system involvement & $10(4.5)$ \\
HLA-B*51† & $81(36.3)$ \\
\hline
\end{tabular}

†HLA-B*51 in controls $=282 / 1,398(20.2 \%) ; P<0.0000001 ; S D$, standard deviation. 
venous thrombosis $(n=26)$. Central nervous system involvement $(n=10)$ included brain parenchymal lesions $(n=6)$, aseptic meningitis $(n=2)$, seizure $(n=$ $1)$, and cranial nerve palsy $(n=1)$. There was no case of gastrointestinal involvement. The $H L A-B * 51$ allele was observed in $36.3 \%$ of patients and $20.2 \%$ of controls $(\mathrm{OR}=2.26, P<0.0000001)$.

\section{Phenotypic frequencies of the HLA-A alleles}

Thirty $H L A-A$ alleles were observed either in patients or controls (Table 2). The phenotypic frequencies of $H L A$ $A * 02: 07(\mathrm{OR}=2.03, P=0.002), A * 26: 01(\mathrm{OR}=1.85$, $P=0.008)$, and $A * 30: 04(\mathrm{OR}=2.51, P=0.006)$ tended to be higher, whereas that of $A * 33: 03$ (OR $=0.59, P=$ 0.003 ) tended to be lower in patients than in controls.

When analyzed in $H L A-B * 51$ non-carriers to exclude the effect of $H L A-B * 51$ (Table 2), the frequencies of $H L A-A * 02: 07$ (OR $=2.00, P=0.010), A * 26: 01$ (OR $=$ 2.18, $P=0.004)$ and $A * 30: 04(\mathrm{OR}=3.52, P=0.002)$ tended to be more frequently observed in patients than in controls. There were no significant differences in the distribution of $H L A-A$ alleles between $H L A-B * 51$ negative and positive patients except for $H L A-A * 33: 03$, and its phenotypic frequency was lower in $H L A-B * 51$ positive than in negative patients $(P=0.047)$.

We could not analyze gene-dose effects of these alleles on the risk of $\mathrm{BD}$ because all patients carrying $H L A$ $A * 02: 07, H L A-A * 26: 01, H L A-A * 30: 04$, or $H L A-A * 33: 03$ allele were heterozygotes except two patients with $H L A$ $A * 02: 07$ allele and one with $H L A-A * 33: 03$ allele.

\section{Meta-analysis of the case-control genetic association studies between HLA-A genes and BD susceptibility}

To overcome the underpowered study design, a metaanalysis was performed. High resolution HLA-A genotyping data upon $\mathrm{BD}$ patients were only available for the Japanese population $[14,25,26]$, thus Japanese data [14] were pooled together with ours using the allelic frequencies. Among $18 H L A-A$ alleles shared by Koreans and the Japanese, the frequencies of $H L A-A * 02: 07, A * 26: 01$, and $A^{*} 26: 03$ were found to be higher and that of $H L A$ $A * 33: 03$ significantly to be lower in BD patients than in controls irrespective of $H L A-B * 51$ status (Table 3 ). In addition, the frequency of $H L A-A^{*} 26: 02$ was found to be higher in $H L A-B * 51$ negative patients than in controls. The between-study heterogeneities were not significant for the above alleles. None of the Japanese individuals carried $H L A-A * 30: 04$ in the previously published studies $[14,22,25,26]$.

\section{Associations between $H L A-A$ alleles and clinical features of $B D$}

The phenotypic frequencies of $H L A-A * 02: 07, A * 26: 01$, $A * 30: 04$, or $A * 33: 03$ alleles were compared between a subset of patients having a particular clinical manifestation (genital ulcers, skin lesions, positive pathergy test, uveitis, arthritis, or vascular lesions) and controls (Table 4). It was found that the $H L A-A * 02: 07$ was associated with skin lesions $(\mathrm{OR}=2.37, P<0.0005, P c<0.012)$ and arthritis $(\mathrm{OR}=2.32, P=0.002, P c=0.048), A * 26: 01$ with uveitis $(\mathrm{OR}=3.01, P<0.0005, P c<0.012)$, and $A * 30: 04$ with vascular lesions $(\mathrm{OR}=9.80, P<0.0005, P c<0.012)$ and positive pathergy test $(\mathrm{OR}=4.10, P=0.002, P c=0.048)$. $H L A-A * 33: 03$ was not associated with any particular manifestations. To further validate the associations between these $H L A-A$ alleles and certain clinical manifestations, we compared the frequencies of $H L A-A * 02: 07, A^{*} 26: 01$, and $A * 30: 04$ between patients with and without a specific clinical manifestation (Table 4). The frequency of $A * 26: 01$ was higher in patients with uveitis than without $(\mathrm{OR}=2.47$, $P=0.029)$ and that of $A * 30: 04$ in patients with vascular lesions than without $(\mathrm{OR}=6.81, P=0.003)$. The frequency of $A * 02: 07$ was only marginally higher in patients with skin lesions than without $(\mathrm{OR}=3.31, P=0.095)$.

\section{Associations between $H L A-A$ alleles and clinical features of $B D$ in $H L A-B * 51$ non-carriers}

To eliminate the effect of $H L A-B * 51$ on the clinical manifestations of $\mathrm{BD}$ (Additional file 1), the analysis was performed in $H L A-B * 51$ non-carriers (Table 4). HLA$A * 02: 07$ was associated with skin lesions $(\mathrm{OR}=2.39$, $P=0.002, P c=0.048)$ and arthritis $(\mathrm{OR}=2.63, P=$ $0.002, P c=0.048), A * 26: 01$ with uveitis $(\mathrm{OR}=4.19, P<$ $0.0005, P c<0.012$ ), and $A * 30: 04$ with vascular lesions $(\mathrm{OR}=13.97, P<0.00005, P c<0.0012)$, genital ulcers (OR $=3.89, P=0.002, P c=0.048)$, and a positive pathergy test $(\mathrm{OR}=5.87, P=0.001, P c=0.024)$; the associations between $H L A-A * 26: 01$ and uveitis and between $H L A-A * 30: 04$ and vascular lesions were much stronger in $H L A-B * 51$ negative patients than in total patients. $H L A-A * 33: 03$ was not associated with any particular manifestations.

The frequency of $H L A-A * 26: 01$ was higher in patients with uveitis than without $(\mathrm{OR}=3.20, P=0.017)$ and that of $H L A-A * 30: 04$ in patients with vascular lesions than without $(\mathrm{OR}=7.53, P=0.003)$.

\section{Distribution of clinical manifestations according to HLA- $B * 51$ and $H L A-A$ status}

Because not only $H L A-A$ alleles but also $H L A-B * 51$ seemed to be associated with skin lesions or uveitis (Table 4, Additional file 1), we stratified the occurrence of skin lesions or uveitis according to the presence or absence of $H L A-B * 51$ and particular $H L A-A$ alleles to better assess the independent effect of $H L A-A * 02: 07$ and $A * 26: 01$ and their genetic interaction with $H L A-B * 51$ on these clinical manifestations (Table 5). There was a trend that $H L A-B * 51$ and $H L A-A * 02: 07$ are additive to 
Table 2 Distribution of phenotypic frequencies of $H L A-A$ alleles

\begin{tabular}{|c|c|c|c|c|c|c|c|c|c|c|c|c|c|c|c|c|c|c|}
\hline \multirow[b]{3}{*}{$A * 01: 01$} & \multicolumn{4}{|c|}{ All subjects } & \multirow{3}{*}{$\begin{array}{c}\text { OR }(95 \% \mathrm{Cl}) \\
0.27 \\
(0.07 \text { to } 1.13)\end{array}$} & \multirow{3}{*}{$\begin{array}{c}P \\
(P c)\end{array}$} & \multicolumn{4}{|c|}{$H L A-B^{*} 51$ non-carriers } & \multirow{3}{*}{$\begin{array}{c}\text { OR }(95 \% \mathrm{Cl}) \\
0.41 \\
(0.10 \text { to } 1.70)\end{array}$} & \multirow{3}{*}{$\begin{array}{c}P \\
(P c)\end{array}$} & \multicolumn{4}{|c|}{$H L A-B^{*} 51$ carriers } & \multirow{3}{*}{$\begin{array}{l}\text { OR }(95 \% \mathrm{Cl}) \\
\mathrm{NA}\end{array}$} & \multirow{3}{*}{$\begin{array}{c}P \\
(P c)\end{array}$} \\
\hline & \multicolumn{2}{|c|}{$\begin{array}{c}\text { BD } \\
N=223\end{array}$} & \multicolumn{2}{|c|}{$\begin{array}{c}\text { Control } \\
N=1,398\end{array}$} & & & \multicolumn{2}{|c|}{$\begin{array}{c}\text { BD } \\
N=142\end{array}$} & \multicolumn{2}{|c|}{$\begin{array}{c}\text { Control } \\
N=1,116\end{array}$} & & & \multicolumn{2}{|c|}{$\begin{array}{c}\text { BD } \\
N=81\end{array}$} & \multicolumn{2}{|c|}{$\begin{array}{l}\text { Control } \\
N=282\end{array}$} & & \\
\hline & 2 & $(0.9)$ & 45 & $(3.2)$ & & & 2 & $(1.4)$ & 38 & $(3.4)$ & & & 0 & $(0.0)$ & 7 & $(2.5)$ & & \\
\hline$A * 02: 01$ & 77 & $(34.5)$ & 433 & $(31.0)$ & $\begin{array}{c}1.18 \\
\text { (0.87 to } 1.58)\end{array}$ & & 46 & $(32.4)$ & 359 & $(32.2)$ & $\begin{array}{c}1.01 \\
(0.70 \text { to } 1.47)\end{array}$ & & 31 & $(38.3)$ & 74 & $(26.2)$ & $\begin{array}{c}1.74 \\
(1.04 \text { to } 2.93)\end{array}$ & $\begin{array}{l}0.035 \\
(>1.0)\end{array}$ \\
\hline$A * 02: 03$ & 4 & (1.8) & 19 & (1.4) & $\begin{array}{c}1.33 \\
\text { (0.45 to } 3.93)\end{array}$ & & 3 & $(2.1)$ & 19 & $(1.7)$ & $\begin{array}{c}1.25 \\
(0.36 \text { to } 4.26)\end{array}$ & & 1 & $(1.2)$ & 0 & $(0.0)$ & NA & \\
\hline$A * 02: 05$ & 0 & $(0.0)$ & 1 & $(0.1)$ & NA & & 0 & $(0.0)$ & 1 & $(0.1)$ & NA & & 0 & $(0.0)$ & 0 & $(0.0)$ & NA & \\
\hline$A * 02: 06$ & 35 & $(15.7)$ & 250 & $(17.9)$ & $\begin{array}{c}0.85 \\
(0.58 \text { to } 1.26)\end{array}$ & & 18 & $(12.7)$ & 193 & $(17.3)$ & $\begin{array}{c}0.69 \\
(0.41 \text { to } 1.17)\end{array}$ & & 17 & $(21.0)$ & 57 & $(20.2)$ & $\begin{array}{c}1.05 \\
\text { (0.57 to } 1.93)\end{array}$ & \\
\hline$A^{* 02: 07}$ & 27 & $(12.1)$ & 89 & $(6.4)$ & $\begin{array}{c}2.03 \\
(1.28 \text { to } 3.20)\end{array}$ & $\begin{array}{l}0.002 \\
(0.06)\end{array}$ & 19 & $(13.4)$ & 80 & $(7.2)$ & $\begin{array}{c}2.00 \\
(1.17 \text { to } 3.41)\end{array}$ & $\begin{array}{l}0.010 \\
(>1.0)\end{array}$ & 8 & (9.9) & 9 & $(3.2)$ & $\begin{array}{c}3.32 \\
(1.24 \text { to } 8.92)\end{array}$ & $\begin{array}{l}0.031 \\
(>1.0)\end{array}$ \\
\hline$A * 02: 10$ & 0 & $(0.0)$ & 13 & $(0.9)$ & NA & & 0 & $(0.0)$ & 12 & $(1.1)$ & NA & & 0 & $(0.0)$ & 1 & $(0.4)$ & NA & \\
\hline$A * 03: 01$ & 3 & (1.4) & 35 & (2.5) & $\begin{array}{c}0.53 \\
(0.16 \text { to } 1.74)\end{array}$ & & 3 & (2.1) & 28 & (2.5) & $\begin{array}{c}0.84 \\
(0.25 \text { to } 2.79)\end{array}$ & & 0 & $(0.0)$ & 7 & (2.5) & NA & \\
\hline$A^{*} 03: 02$ & 1 & $(0.5)$ & 6 & (0.4) & $\begin{array}{c}1.05 \\
(0.13 \text { to } 8.72)\end{array}$ & & 1 & $(0.7)$ & 5 & $(0.5)$ & $\begin{array}{c}1.58 \\
\text { (0.18 to } 13.59)\end{array}$ & & 0 & $(0.0)$ & 1 & (0.4) & NA & \\
\hline$A^{* 11: 01}$ & 39 & $(17.5)$ & 242 & (17.3) & $\begin{array}{c}1.01 \\
\text { (0.70 to } 1.47)\end{array}$ & & 25 & $(17.6)$ & 188 & (16.9) & $\begin{array}{c}1.05 \\
(0.67 \text { to } 1.67)\end{array}$ & & 14 & (17.3) & 54 & (19.2) & $\begin{array}{c}0.88 \\
(0.46 \text { to } 1.69)\end{array}$ & \\
\hline$A^{* 11: 02}$ & 2 & (0.9) & 2 & $(0.1)$ & $\begin{array}{c}6.32 \\
\text { (0.89 to } 45.08)\end{array}$ & & 1 & $(0.7)$ & 1 & $(0.1)$ & $\begin{array}{c}7.91 \\
\text { (0.49 to } 127 \text { to } 13)\end{array}$ & & 1 & $(1.2)$ & 1 & (0.4) & $\begin{array}{c}3.5 \\
(0.22 \text { to } 56.58)\end{array}$ & \\
\hline$A^{*} 24: 02$ & 95 & $(42.6)$ & 578 & $(41.3)$ & $\begin{array}{c}1.05 \\
(0.79 \text { to } 1.40)\end{array}$ & & 54 & $(38.0)$ & 442 & (39.6) & $\begin{array}{c}0.94 \\
(0.65 \text { to } 1.34)\end{array}$ & & 41 & (50.6) & 136 & $(48.2)$ & $\begin{array}{c}1.10 \\
(0.67 \text { to } 1.80)\end{array}$ & \\
\hline$A^{*} 24: 03$ & 0 & $(0.0)$ & 1 & $(0.1)$ & NA & & 0 & $(0.0)$ & 1 & $(0.1)$ & NA & & 0 & $(0.0)$ & 0 & $(0.0)$ & NA & \\
\hline$A * 24: 04$ & 0 & $(0.0)$ & 1 & $(0.1)$ & NA & & 0 & $(0.0)$ & 1 & $(0.1)$ & NA & & 0 & $(0.0)$ & 0 & $(0.0)$ & NA & \\
\hline$A * 24: 08$ & 0 & $(0.0)$ & 1 & $(0.1)$ & NA & & 0 & $(0.0)$ & 1 & $(0.1)$ & NA & & 0 & $(0.0)$ & 0 & $(0.0)$ & NA & \\
\hline$A * 24: 20$ & 1 & (0.5) & 2 & $(0.1)$ & $\begin{array}{c}3.14 \\
\text { (0.28 to } 34.82)\end{array}$ & & 1 & $(0.7)$ & 2 & $(0.2)$ & $\begin{array}{c}3.95 \\
\text { (0.36 to } 43.84)\end{array}$ & & 0 & $(0.0)$ & 0 & $(0.0)$ & NA & \\
\hline$A * 26: 01$ & 26 & $(11.7)$ & 93 & (6.7) & $\begin{array}{c}1.85 \\
(1.17 \text { to } 2.93)\end{array}$ & $\begin{array}{l}0.008 \\
(0.24)\end{array}$ & 19 & (13.4) & 74 & (6.6) & $\begin{array}{c}2.18 \\
(1.27 \text { to } 3.72)\end{array}$ & $\begin{array}{l}0.004 \\
(0.12)\end{array}$ & 7 & (8.6) & 19 & (6.7) & $\begin{array}{c}1.31 \\
(0.53 \text { to } 3.23)\end{array}$ & \\
\hline$A * 26: 02$ & 11 & (4.9) & 58 & (4.2) & $\begin{array}{c}1.20 \\
\text { (0.62 to } 2.32)\end{array}$ & & 7 & (4.9) & 46 & (4.1) & 1.21 (0.53 to 2.73) & & 4 & $(4.9)$ & 12 & $(4.3)$ & $\begin{array}{c}1.17 \\
(0.37 \text { to } 3.72)\end{array}$ & \\
\hline$A * 26: 03$ & 7 & (3.1) & 17 & $(1.2)$ & $\begin{array}{c}2.63 \\
(1.08 \text { to } 6.42)\end{array}$ & $\begin{array}{l}0.037 \\
(>1.0)\end{array}$ & 5 & (3.5) & 14 & (1.3) & $\begin{array}{c}2.87 \\
(1.02 \text { to } 8.10)\end{array}$ & 0.053 & 2 & $(2.5)$ & 3 & $(1.1)$ & $\begin{array}{c}2.35 \\
\text { (0.39 to } 14.34)\end{array}$ & \\
\hline$A * 26: 05$ & 0 & $(0.0)$ & 1 & $(0.1)$ & NA & & 0 & $(0.0)$ & 0 & $(0.0)$ & NA & & 0 & $(0.0)$ & 1 & $(0.4)$ & NA & \\
\hline$A * 26: 18$ & 0 & $(0.0)$ & 1 & $(0.1)$ & NA & & 0 & $(0.0)$ & 1 & $(0.1)$ & NA & & 0 & $(0.0)$ & 0 & $(0.0)$ & NA & \\
\hline$A * 29: 01$ & 2 & $(0.9)$ & 28 & $(2.0)$ & $\begin{array}{c}0.44 \\
(0.10 \text { to } 1.87)\end{array}$ & & 2 & (1.4) & 24 & $(2.2)$ & $\begin{array}{c}0.65 \\
(0.15 \text { to } 2.78)\end{array}$ & & 0 & $(0.0)$ & 4 & $(1.4)$ & NA & \\
\hline$A * 29: 02$ & 1 & $(0.5)$ & 0 & $(0.0)$ & NA & & 1 & $(0.7)$ & 0 & $(0.0)$ & NA & & 0 & $(0.0)$ & 0 & $(0.0)$ & NA & \\
\hline
\end{tabular}


Table 2 Distribution of phenotypic frequencies of HLA-A alleles (Continued)

\begin{tabular}{|c|c|c|c|c|c|c|c|c|c|c|c|c|c|c|c|c|c|}
\hline$\overline{A * 30: 01}$ & 8 & (3.6) & 74 & (5.3) & $\begin{array}{c}0.67 \\
(0.32 \text { to } 1.40)\end{array}$ & & 7 & (4.9) & 63 & $(5.7)$ & $\begin{array}{c}0.87 \\
\text { (0.39 to } 1.93)\end{array}$ & & 1 & $(1.2)$ & 11 & (3.9) & $\begin{array}{c}0.31 \\
\text { (0.04 to } 2.42)\end{array}$ \\
\hline$A^{*} 30: 04$ & 12 & (5.4) & 31 & (2.2) & $\begin{array}{c}2.51 \\
(1.27 \text { to } 4.96)\end{array}$ & $\begin{array}{l}0.006 \\
(0.18)\end{array}$ & 11 & (7.8) & 26 & (2.3) & $\begin{array}{c}3.52 \\
(1.70 \text { to } 7.29)\end{array}$ & $\begin{array}{l}0.002 \\
(0.06)\end{array}$ & 1 & $(1.2)$ & 5 & $(1.8)$ & $\begin{array}{c}0.69 \\
\text { (0.08 to } 6.01)\end{array}$ \\
\hline$A * 31: 01$ & 22 & (9.9) & 160 & (11.4) & $\begin{array}{c}0.85 \\
\text { (0.53 to } 1.35)\end{array}$ & & 10 & (7.0) & 98 & (8.8) & $\begin{array}{c}0.79 \\
(0.40 \text { to } 1.55)\end{array}$ & & 12 & (14.8) & 62 & (22.0) & $\begin{array}{c}0.62 \\
(0.31 \text { to } 1.21)\end{array}$ \\
\hline$A * 31: 11$ & 0 & $(0.0)$ & 1 & $(0.1)$ & NA & & 0 & (0.0) & 0 & $(0.0)$ & NA & & 0 & $(0.0)$ & 1 & $(0.4)$ & NA \\
\hline$A * 32: 01$ & 0 & $(0.0)$ & 26 & (1.9) & NA & & 0 & (0.0) & 25 & (2.2) & NA & & 0 & $(0.0)$ & 1 & $(0.4)$ & NA \\
\hline$A * 33: 03$ & 43 & (19.3) & 405 & (29.0) & $\begin{array}{c}0.59 \\
(0.41 \text { to } 0.83)\end{array}$ & $\begin{array}{l}0.003 \\
(0.09)\end{array}$ & 33 & $(23.2) \dagger$ & 345 & (30.9) & $\begin{array}{c}0.68 \\
(0.45 \text { to } 1.02)\end{array}$ & & 10 & (12.4) & 60 & (21.3) & $\begin{array}{c}0.52 \\
(0.25 \text { to } 1.07)\end{array}$ \\
\hline$A^{*} 68: 01$ & 1 & $(0.5)$ & 3 & $(0.2)$ & $\begin{array}{c}2.09 \\
(0.22 \text { to } 20.23)\end{array}$ & & 1 & $(0.7)$ & 2 & $(0.2)$ & $\begin{array}{c}3.95 \\
\text { (0.36 to } 43.85)\end{array}$ & & 0 & $(0.0)$ & 1 & $(0.4)$ & NA \\
\hline
\end{tabular}

Values are presented as $\mathrm{N}(\%) . P\left(P_{C}\right)$ values are presented for those alleles with estimable $\mathrm{OR}(95 \% \mathrm{Cl})$ and $P$-values of $<0.05$

$\dagger P=0.047$ (HLA-B*51 negative vs. positive patients). BD, Behcet's disease; $\mathrm{Cl}$, confidence intervals; NA, not applicable; $\mathrm{OR}$, odds ratio; $P C$, corrected $P$. 
Table 3 Meta-analysis on the association between HLA-A alleles and BD†

\begin{tabular}{|c|c|c|c|c|c|c|c|c|c|c|}
\hline \multirow[t]{2}{*}{ Allele } & \multicolumn{5}{|c|}{ Total subjects } & \multicolumn{5}{|c|}{$H L A-B * 51$ non-carriers } \\
\hline & OR $(95 \% \mathrm{Cl})$ & $P$ & $\begin{array}{l}1^{2} \\
(\%)\end{array}$ & $P_{\text {het }}$ & $\begin{array}{c}\text { Weight } \\
\text { (\%) }\end{array}$ & OR $(95 \% \mathrm{Cl})$ & $P$ & $\begin{array}{l}1^{2} \\
(\%)\end{array}$ & $P_{\text {het }}$ & $\begin{array}{c}\text { Weight } \\
(\%)\end{array}$ \\
\hline$A^{*} 01: 01$ & 0.54 (0.21 to 1.42$)$ & 0.21 & 76 & 0.04 & 92.7 & $0.65(0.22$ to 1.91$)$ & 0.43 & 60 & 0.11 & 92.7 \\
\hline$A^{*} 02: 01$ & 1.20 (0.97 to 1.48$)$ & 0.09 & 0 & 0.70 & 65.7 & 1.13 (0.87 to 1.47$)$ & 0.37 & 0 & 0.33 & 70.5 \\
\hline$A * 02: 03$ & 0.96 (0.35 to 2.65$)$ & 0.93 & 27 & 0.24 & 67.5 & 0.99 (0.32 to 3.09) & 0.99 & 0 & 0.47 & 70.9 \\
\hline$A * 02: 06$ & 0.86 (0.66 to 1.13$)$ & 0.28 & 0 & 0.69 & 58.2 & $0.73(0.50$ to 1.06$)$ & 0.10 & 0 & 0.62 & 60.7 \\
\hline$A * 02: 07$ & 1.96 (1.34 to 2.85$)$ & 0.0005 & 0 & 0.62 & 66.6 & $2.00(1.30$ to 3.09$)$ & 0.002 & 0 & 0.69 & 69.7 \\
\hline$A^{*} 02: 10$ & 0.37 (0.06 to 2.37) & 0.30 & 0 & 0.43 & 80.0 & 0.37 (0.05 to 3.05$)$ & 0.36 & 0 & 0.72 & 74.5 \\
\hline$A * 03: 01$ & 0.44 (0.15 to 1.26$)$ & 0.13 & 0 & 0.56 & 71.1 & 0.77 (0.26 to 2.21$)$ & 0.62 & 0 & 0.84 & 75.7 \\
\hline$A * 03: 02$ & 0.71 (0.12 to 4.21$)$ & 0.70 & 0 & 0.56 & 52.4 & 1.12 (0.18 to 6.77$)$ & 0.90 & 0 & 0.64 & 51.9 \\
\hline$A * 11: 01$ & 0.78 (0.60 to 1.03 ) & 0.08 & 77 & 0.04 & 50.5 & 0.85 (0.61 to 1.19$)$ & 0.35 & 51 & 0.15 & 50.6 \\
\hline$A^{*} 11: 02$ & 1.30 (0.30 to 5.57$)$ & 0.73 & 75 & 0.05 & 18.0 & $1.23(0.20$ to 7.71$)$ & 0.82 & 57 & 0.13 & 11.5 \\
\hline$A^{*} 24: 02$ & 0.89 (0.75 to 1.05$)$ & 0.18 & 44 & 0.18 & 47.0 & 0.83 (0.67 to 1.03$)$ & 0.10 & 0 & 0.43 & 48.8 \\
\hline$A * 24: 20$ & 0.60 (0.13 to 2.83$)$ & 0.52 & 59 & 0.12 & 12.1 & 0.68 (0.12 to 3.73$)$ & 0.65 & 63 & 0.10 & 12.6 \\
\hline$A * 26: 01$ & 1.89 (1.41 to 2.53 ) & $<0.0001$ & 0 & 0.91 & 38.9 & 2.42 (1.73 to 3.39$)$ & $<0.00001$ & 0 & 0.62 & 41.3 \\
\hline$A * 26: 02$ & 1.48 (0.90 to 2.42 ) & 0.12 & 7 & 0.30 & 64.5 & 1.93 (1.09 to 3.40$)$ & 0.02 & 69 & 0.07 & 69.1 \\
\hline$A * 26: 03$ & 2.01 (1.14 to 3.56$)$ & 0.02 & 0 & 0.51 & 28.4 & $2.40(1.17$ to 4.91$)$ & 0.02 & 0 & 0.70 & 36.6 \\
\hline$A * 26: 05$ & 3.69 (0.44 to 31.24$)$ & 0.23 & 0 & 0.69 & 45.3 & NA & & & & \\
\hline$A * 31: 01$ & 1.22 (0.91 to 1.62$)$ & 0.18 & 79 & 0.03 & 51.9 & $0.73(0.45$ to 1.19$)$ & 0.21 & 0 & 0.76 & 51.8 \\
\hline$A * 33: 03$ & 0.52 (0.39 to 0.70$)$ & $<0.00001$ & 64 & 0.09 & 71.0 & 0.58 (0.41 to 0.81$)$ & 0.001 & 67 & 0.08 & 71.3 \\
\hline
\end{tabular}

†Genetic data were pooled using allelic frequency.

$\mathrm{Cl}$, confidence interval; $\mathrm{I}^{2}$, between-study heterogeneity; NA, not applicable; OR, odds ratios for the risk to develop BD; $P, P$-values for significance of each $H L A-A$ allele in the pooled genetic effect (calculated by Mantel-Haenszel fixed method); $P_{\text {het }}, P$ values for heterogeneity statistics; weight (\%), weight of the present study.

increase the risk of skin lesions, which, however, was not statistically significant, probably due to the limited power of analysis. While both $H L A-B * 51$ and $H L A$ $A * 26: 01$ seemed to be risk factors for uveitis, the risk to uveitis was not escalated with the combination of $H L A$ $B * 51$ and $H L A-A * 26: 01$ than with either one of the two alleles.

\section{Discussion}

The present study shows that three $H L A-A$ alleles, $A * 02: 07, A^{*} 26: 01$, and $A * 30: 04$ might be BD susceptibility alleles, while $A * 33: 03$ may be a protective one in the Korean population. It was also found that $A^{* 02: 07}$ is associated with skin lesions and arthritis, $A * 26: 01$ with uveitis, and $A * 30: 04$ with vascular lesions, genital ulcers, and positive pathergy test, independently of $H L A-B * 51$. The meta-analysis performed in the present study confirmed that $H L A-A * 02: 07$ and $A * 26: 01$ are BD susceptibility alleles, whereas $H L A-A * 33: 03$ is associated with decreased risk of BD.

Although many studies investigated the HLA-class I region in $\mathrm{BD}$ patients, the majority reported insignificant results for $H L A-A$ alleles; there was no significant $H L A-$ $A$ allele associated with BD in Palestine, Jordan, Iran, Ireland, Italy, and Turkey [27-31]. The low phenotypic frequencies of $H L A-A * 02: 07, A * 26: 01$, and $A * 30: 04$ in BD patients, which ranged between 5 and $15 \%$ in the present study, might have rendered it difficult to find associations between these $H L A-A$ alleles and clinical manifestations in the previous studies that adopted a relatively small number of subjects. However, recent GWAS consistently showed that HLA-A region adds an independent contribution to the risk of BD [14-16].

The associations among $H L A-A * 02: 07$ and skin lesions and arthritis, and among $H L A-A * 30: 04$ and vascular lesions, genital ulcers, and positive pathergy test were revealed for the first time in the present study. Interestingly, not only $H L A-A * 02: 07$ but also $H L A-B * 51$ appears to be a susceptibility allele for skin lesions (Table 4, Additional file 1). Furthermore, the majority of patients negative for both $H L A-B^{*} 51$ and $H L A-A * 02: 07$ exhibited skin lesions (Table 5), which suggests a large contribution of additional genetic loci to the skin manifestation of $\mathrm{BD}$. Although $H L A-A * 30: 04$ was strongly associated with vascular lesions in the Korean population, no study subject carried the $H L A-A * 30: 04$ allele in the Japanese subjects $[14,22,25,26]$ despite a high frequency of vascular involvement reported in Japanese BD patients [32]. These findings reveal a striking genetic difference, and we suggest that our result be compared with those obtained in other ethnic groups with sufficient $H L A-A * 30: 04$ carriers, if any. On the other hand, we are cautious to claim conclusively the specific associations between $H L A-A * 02: 07$ and arthritis or between $H L A-A * 30: 04$ and genital ulcers and a 
Table 4 Associations between $H L A-A$ alleles and clinical manifestations of BD

\begin{tabular}{|c|c|c|c|c|c|}
\hline HLA alleles & Group & $\begin{array}{c}\text { Phenotypic frequency } \\
n(\%)\end{array}$ & OR $(95 \% \mathrm{Cl})$ & $P$ & Pc \\
\hline & All s & & & & \\
\hline \multirow[t]{6}{*}{$A^{*} 02: 07$} & Patients with skin lesions $(n=180)$ & $25(13.9)$ & & & \\
\hline & vs. Patients without skin lesions $(n=43)$ & $2(4.7)$ & 3.31 (0.75 to 14.54$)$ & 0.095 & \\
\hline & vs. Controls ( $n=1,398)$ & $89(6.4)$ & 2.37 (1.48 to 3.31$)$ & $<0.0005$ & $<0.012$ \\
\hline & Patients with arthritis $(n=125)$ & $17(13.6)$ & & & \\
\hline & vs. Patients without arthritis $(n=98)$ & $10(10.2)$ & 1.39 (0.60 to 3.18$)$ & 0.438 & \\
\hline & vs. Controls $(n=1,398)$ & $89(6.4)$ & $2.32(1.33$ to 4.03$)$ & 0.002 & 0.048 \\
\hline \multirow[t]{3}{*}{$A^{*} 26: 01$} & Patients with uveitis $(n=85)$ & $15(17.7)$ & & & \\
\hline & vs. Patients without uveitis $(n=138)$ & $11(8.0)$ & 2.47 (1.08 to 5.68$)$ & 0.029 & \\
\hline & vs. Controls $(n=1,398)$ & $93(6.7)$ & 3.01 (1.66 to 5.46$)$ & $<0.0005$ & $<0.012$ \\
\hline \multirow[t]{10}{*}{$A^{*} 30: 04$} & Patients with vascular lesions $(n=33)$ & $6(18.2)$ & & & \\
\hline & vs. Patients without vascular lesions $(n=190)$ & $6(3.2)$ & 6.81 (2.05 to 22.66) & 0.003 & \\
\hline & vs. Controls ( $n=1,398)$ & $31(2.2)$ & 9.80 (3.78 to 25.43 ) & $<0.0005$ & $<0.012$ \\
\hline & Patients with genital ulcers $(n=159)$ & $10(6.3)$ & & & \\
\hline & vs. Patients without genital ulcers $(n=64)$ & $2(3.1)$ & 2.08 (0.44 to 9.77$)$ & 0.516 & \\
\hline & vs. Controls ( $n=1,398)$ & $31(2.2)$ & $3.00(1.42$ to 6.16$)$ & 0.006 & 0.14 \\
\hline & Patients with positive pathergy test $(n=94)$ & $8(8.5)$ & & & \\
\hline & vs. Patients with negative pathergy test $(n=88)$ & $3(3.4)$ & 2.19 (0.74 to 6.46$)$ & 0.147 & \\
\hline & vs. Controls $(n=1,398)$ & $31(2.2)$ & 4.10 (1.83 to 9.20$)$ & 0.002 & 0.048 \\
\hline & $H L A-B^{*} 51$ & -carriers & & & \\
\hline \multirow[t]{6}{*}{$A^{*} 02: 07$} & Patients with skin lesions $(n=109)$ & $17(15.6)$ & & & \\
\hline & vs. Patients without skin lesions $(n=33)$ & $2(6.1)$ & 2.86 (0.63 to 13.10$)$ & 0.243 & \\
\hline & vs. Controls $(n=1,116)$ & $80(7.2)$ & 2.39 (1.36 to 4.21$)$ & 0.002 & 0.048 \\
\hline & Patients with arthritis $(n=83)$ & $14(16.9)$ & & & \\
\hline & vs. Patients without arthritis $(n=59)$ & $5(8.5)$ & 2.19 (0.74 to 6.46$)$ & 0.147 & \\
\hline & vs. Controls ( $n=1,116)$ & $80(7.2)$ & 2.63 (1.42 to 4.87$)$ & 0.002 & 0.048 \\
\hline \multirow[t]{3}{*}{$A^{*} 26: 01$} & Patients with uveitis $(n=48)$ & $11(22.9)$ & & & \\
\hline & vs. Patients without uveitis $(n=94)$ & $8(8.5)$ & $3.20(1.19$ to 8.59$)$ & 0.017 & \\
\hline & vs. Controls $(n=1,116)$ & $74(6.6)$ & 4.19 (2.05 to 8.54$)$ & $<0.0005$ & $<0.012$ \\
\hline \multirow[t]{9}{*}{$A^{*} 30: 04$} & Patients with vascular lesions $(n=24)$ & $6(25.0)$ & & & \\
\hline & vs. Patients without vascular lesions $(n=118)$ & $5(4.2)$ & 7.53 (2.08 to 27.28) & 0.003 & \\
\hline & vs. Controls $(n=1,116)$ & $26(2.3)$ & $13.97(5.13$ to 38.08$)$ & $<0.00005$ & $<0.0012$ \\
\hline & Patients with genital ulcers $(n=106)$ & $9(8.5)$ & & & \\
\hline & vs. Patients without genital ulcers $(n=36)$ & $2(5.6)$ & $1.58(0.32$ to 7.67$)$ & 0.730 & \\
\hline & vs. Controls ( $n=1,116)$ & $26(2.3)$ & 3.89 (1.77 to 8.54$)$ & 0.002 & 0.048 \\
\hline & Patients with positive pathergy test $(n=57)$ & $7(12.3)$ & & & \\
\hline & vs. Patients with negative pathergy test ( $n=58$ ) & $3(5.2)$ & 2.57 (0.63 to 10.47$)$ & 0.203 & \\
\hline & vs. Controls $(n=1,116)$ & $26(2.3)$ & 5.87 (2.43 to 14.17$)$ & 0.001 & 0.024 \\
\hline
\end{tabular}

$\mathrm{Cl}$, confidence interval; $\mathrm{OR}$, odds ratio; $P$,,$P$-values corrected for multiple testing.

positive pathergy test, because patients without these clinical manifestations showed higher phenotypic frequencies of HLA-A*02:07 or $A * 30: 04$ than controls (Table 4). Moreover, these associations were not significant when patients with and without a particular clinical manifestation were compared. Therefore, there is a possibility that the above associations are merely due to increased disease susceptibility related to $H L A-A * 02: 07$ and $A * 30: 04$.

Elevated frequencies of $H L A-A * 26$ have been reported in $\mathrm{BD}$ patients in Greece [19] and in patients with ocular manifestation in Taiwan [18]. HLA-A*26:01 not only has been reported to be a primary susceptibility allele of BD in Japan [14], but a recent study also found that the frequency of $H L A-A * 26: 01$ was significantly increased in $\mathrm{BD}$ patients with uveitis, particularly in the $H L A-B * 51$ negative subset, in this ethnic group [33]. These findings are consistent with the present study. In addition, the decreased frequency of $H L A-A * 33: 03$ in $\mathrm{BD}$ patients in our study is consistent with the result obtained in the Japanese GWAS [14]. 
Table 5 Distribution of clinical manifestations according to $H L A-B * 51$ and $H L A-A$ status

\begin{tabular}{|c|c|c|c|}
\hline Patient subset & $n(\%)$ of clinical manifestations & OR $(95 \% \mathrm{Cl})$ & $P$ \\
\hline & Skin lesions & & \\
\hline$B * 51+A * 02: 07+$ & $8 / 8(100)$ & NA & 0.20 \\
\hline$B * 51-A * 02: 07+$ & $17 / 19(89.5)$ & 2.86 (0.63 to 13.10$)$ & 0.24 \\
\hline$B * 51+A^{* 02: 07-}$ & 63/73 (86.3) & 2.12 (0.97 to 4.64$)$ & 0.055 \\
\hline \multirow[t]{2}{*}{$B * 51-A * 02: 07-$} & $92 / 123(74.8)$ & (referent) & \\
\hline & Uveitis & & \\
\hline$B * 51+A * 26: 01+$ & $4 / 7(57.1)$ & 3.10 (0.66 to 14.53$)$ & 0.21 \\
\hline$B * 51-A * 26: 01+$ & $11 / 19(57.9)$ & 3.20 (1.19 to 8.59$)$ & 0.017 \\
\hline$B * 51+A * 26: 01-$ & $33 / 74((44.6)$ & $1.87(1.03$ to 3.40$)$ & 0.039 \\
\hline$B * 51-A * 26: 01-$ & $37 / 123(30.1)$ & (referent) & \\
\hline
\end{tabular}

$\mathrm{Cl}$, confidence intervals; $\mathrm{NA}$, not applicable; OR, odds ratio.

Although our results remain to be replicated in other cohorts, this is one of the few studies that comprehensively investigated the impact of the $H L A-A$ gene on BD in relation to $H L A-B * 51$. To avoid false negative results when assessing the association between certain $H L A-A$ alleles and clinical manifestations of $\mathrm{BD}$, we compared each clinical subset with a large number of controls. Then, patients with and without specific clinical manifestations were compared to validate the identified associations. Our results clearly show that certain $H L A-A$ alleles are responsible for the unique clinical features of $\mathrm{BD}$. The lack of individual demographic data of the controls might be one of the limitations of this study. Nevertheless, we believe that the results of our study are unlikely to be affected by systematic errors such as population stratification because the source of our controls, the unrelated hematopoietic stem cell donor registry of the KONOS, represents the whole Korean population rather than certain social groups within the population.

\section{Conclusions}

This study investigated $H L A-A$ alleles in BD patients and analyzed genetic susceptibilities to clinical manifestations of BD and found that $H L A-A * 02: 07, A^{*} 26: 01$, and $A * 30: 04$ may be BD susceptibility alleles in the Korean population and are associated with skin lesions and arthritis, with ocular lesions, and with vascular lesions, genital ulcers, and positive pathergy test, respectively.

\section{Additional material}

Additional file 1: The effect of HLA-B*51 on clinical manifestations of $\mathrm{BD}$.

\section{Abbreviations}

BD: Behcet's disease; Cl: confidence intervals; GWAS: genome wide association studies; KONOS: Korean Network for Organ Sharing; OR: odds ratio; PC: corrected P; PCR: polymerase chain reaction;

\section{Acknowledgements}

This study was advised by the statistical expert team of Medical Research Collaborating Center, Seoul National University College of Medicine, Seoul, Korea and supported by a grant of the Korea Healthcare technology R\&D Project (A080588), Ministry for Health, Welfare and Family Affairs, Republic of Korea

\section{Author details}

'Division of Rheumatology, Department of Internal Medicine, Seoul National University Bundang Hospital, 166 Gumi-ro, Bundang-gu, Seongnam-si, Gyeonggi-do, Korea. ${ }^{2}$ Division of Rheumatology, Department of Internal Medicine, Seoul National University Hospital, 28 Yeongeon-dong, Jongno-gu, Seoul, Korea. ${ }^{3}$ Department of Internal Medicine, Faculty of Medicine, University of Tokyo, 7-3-1, Hongo, Bunkyo-ku, Tokyo, 113-0033, Japan. ${ }^{4}$ Institute of Rheumatology, Medical Research Center, Seoul National University Hospital, 28 Yeongeon-dong, Jongno-gu, Seoul, Korea.

${ }^{5}$ Department of Laboratory Medicine, Seoul National University Hospital, 28 Yeongeon-dong, Jongno-gu, Seoul, Korea.

\section{Authors' contributions}

EHK collected the clinical data, performed statistical analysis, and drafted the manuscript. JYK genotyped the HLA gene. FT helped design the study. JWK helped collect the clinical data. KS, EYL, YJL, EBL and MHP helped interpret the data. YWS was involved in the conception and design of the study. All authors read and approved the final manuscript.

\section{Competing interests}

The authors declare that they have no competing interests.

Received: 24 November 2010 Revised: 4 March 2011

Accepted: 24 March 2011 Published: 24 March 2011

\section{References}

1. Sakane T, Takeno M, Suzuki N, Inaba G: Behçet's disease. N Engl J Med 1999, 341:1284-1291.

2. Gül A, Inanç M, Ocal L, Aral O, Koniçe M: Familial aggregation of Behçet's disease in Turkey. Ann Rheum Dis 2000, 59:622-625.

3. Koné-Paut I, Geisler I, Wechsler B, Ozen S, Ozdogan H, Rozenbaum M, Touitou I: Familial aggregation in Behçet's disease: high frequency in siblings and parents of pediatric probands. J Pediatr 1999, 135:89-93.

4. Verity DH, Marr JE, Ohno S, Wallace GR, Stanford MR: Behçet's disease, the Silk Road and HLA-B51: historical and geographical perspectives. Tissue Antigens 1999, 54:213-220.

5. Ohno S, Ohguchi M, Hirose S, Matsuda H, Wakisaka A, Aizawa M: Close association of HLA-Bw51 with Behçet's disease. Arch Ophthalmol 1982, 100:1455-1458.

6. Yazici H, Fresko I, Yurdakul S: Behçet's syndrome: disease manifestations, management, and advances in treatment. Nat Clin Pract Rheumatol 2007, 3:148-155.

7. Mizuki N, Ota M, Kimura M, Ohno S, Ando H, Katsuyama Y, Yamazaki M, Watanabe K, Goto K, Nakamura S, Bahram S, Inoko H: Triplet repeat polymorphism in the transmembrane region of the MICA gene: a strong 
association of six GCT repetitions with Behçet disease. Proc Natl Acad Sci USA 1997, 94:1298-1303.

8. Touma Z, Farra C, Hamdan A, Shamseddeen W, Uthman I, Hourani H, Arayssi T: TNF polymorphisms in patients with Behçet disease: a metaanalysis. Arch Med Res 2010, 41:142-146.

9. Lee EB, Kim JY, Zhao J, Park MH, Song YW: Haplotype association of IL-8 gene with Behcet's disease. Tissue Antigens 2007, 69:128-132.

10. Salvarani C, Boiardi L, Casali B, Olivieri I, Ciancio G, Cantini F, Salvi F, Malatesta R, Govoni M, Trotta F, Filippini D, Paolazzi G, Nicoli D, Farnetti E, Macchioni P: Endothelial nitric oxide synthase gene polymorphisms in Behçet's disease. J Rheumatol 2002, 29:535-540.

11. Lee YJ, Kang SW, Baek HJ, Choi HJ, Bae YD, Kang EH, Lee EY, Lee EB, Song YW: Association between matrix metalloproteinase 9 promoter polymorphisms and Behçet's disease. Hum Immunol 2010, 71:717-722.

12. Karasneh J, Gül A, Ollier WE, Silman AJ, Worthington J: Whole-genome screening for susceptibility genes in multicase families with Behçet's disease. Arthritis Rheum 2005, 52:1836-1842.

13. Fei $Y$, Webb R, Cobb BL, Direskeneli H, Saruhan-Direskeneli G, Sawalha AH: Identification of novel genetic susceptibility loci for Behçet's disease using a genome-wide association study. Arthritis Res Ther 2009, 11:R66.

14. Meguro A, Inoko H, Ota M, Katsuyama Y, Oka A, Okada E, Yamakawa R, Yuasa T, Fujioka T, Ohno S, Bahram S, Mizuki N: Genetics of Behçet disease inside and outside the MHC. Ann Rheum Dis 2010, 69:747-754.

15. Mizuki N, Meguro A, Ota M, Ohno S, Shiota T, Kawagoe T, Ito N, Kera J, Okada E, Yatsu K, Song YW, Lee EB, Kitaichi N, Namba K, Horie Y, Takeno M, Sugita S, Mochizuki M, Bahram S, Ishigatsubo Y, Inoko H: Genome-wide association studies identify IL23R-IL12RB2 and IL10 as Behçet's disease susceptibility loci. Nat Genet 2010, 42:703-706

16. Remmers EF, Cosan F, Kirino $Y$, Ombrello MJ, Abaci N, Satorius C, Le JM, Yang B, Korman BD, Cakiris A, Aglar O, Emrence Z, Azakli H, Ustek D, TugalTutkun I, Akman-Demir G, Chen W, Amos Cl, Dizon MB, Kose AA, Azizlerli G, Erer B, Brand OJ, Kaklamani VG, Kaklamanis P, Ben-Chetrit E, Stanford M, Fortune F, Ghabra M, Ollier WE, et al: Genome-wide association study identifies variants in the MHC class I, IL10, and IL23R-IL12RB2 regions associated with Behçet's disease. Nat Genet 2010, 42:698-702.

17. Itoh Y, Inoko H, Kulski JK, Sasaki S, Meguro A, Takiyama N, Nishida T, Yuasa T, Ohno S, Mizuki N: Four-digit allele genotyping of the HLA-A and HLA-B genes in Japanese patients with Behcet's disease by a PCR-SSOPLuminex method. Tissue Antigens 2006, 67:390-394.

18. Chung YM, Yeh TS, Sheu MM, Chen MS, Wen MS, Tsai HY, Liao HR: Behcet's disease with ocular involvement in Taiwan: a joint survey of six major ophthalmological departments. J Formos Med Assoc 1990, 89:413-417.

19. Mizuki N, Ohno S, Ando H, Chen L, Palimeris GD, Stavropoulos-Ghiokas E, Ishihara M, Goto K, Nakamura S, Shindo Y, Isobe K, Ito N, Inoko H: A strong association between $H L A-B * 5101$ and Behçet's disease in Greek patients. Tissue Antigens 1997, 50:57-60.

20. Criteria for diagnosis of Behçet's disease. International Study Group for Behçet's Disease. Lancet 1990, 335:1078-1080.

21. Lee EB, Yoo JE, Lee YJ, Choi YJ, Park KS, Song YW: Tumor necrosis factor receptor 2 polymorphism in systemic lupus erythematosus: no association with disease. Hum Immunol 2001, 62:1148-1152.

22. Itoh Y, Mizuki N, Shimada T, Azuma F, Itakura M, Kashiwase K, Kikkawa E, Kulski JK, Satake M, Inoko H: High-throughput DNA typing of HLA-A, -B, $-C$, and -DRB1 loci by a PCR-SSOP-Luminex method in the Japanese population. Immunogenetics 2005, 57:717-729.

23. Mantel $\mathrm{N}$, Haenszel W: Statistical aspects of the analysis of data from retrospective studies of disease. J Natl Cancer Inst 1959, 22:719-748.

24. Higgins JP, Thompson SG, Deeks JJ, Altman DG: Measuring inconsistency in meta-analyses. BMJ 2003, 327:557-560.

25. Itoh Y, Inoko H, Kulski JK, Sasaki S, Meguro A, Takiyama N, Nishida T, Yuasa T, Ohno S, Mizuki N: Four-digit allele genotyping of the HLA-A and HLA-B genes in Japanese patients with Behcet's disease by a PCR-SSOPLuminex method. Tissue Antigens 2006, 67:390-394.

26. Kamiishi T, Itoh Y, Meguro A, Nishida T, Sasaki S, Nanba K, Ohno S, Inoko H, Mizuki N: Four-digit allele genotyping of HLA-A and HLA-B genes in Japanese patients with Behçet's disease (BD) by a PCR-SSOP-luminex method and stratification analysis according to each major symptom of BD. Nippon Ganka Gakkai Zasshi 2008, 112:451-458.

27. Verity DH, Wallace GR, Vaughan RW, Kondeatis E, Madanat W, Zureikat $H$, Fayyad F, Marr JE, Kanawati CA, Stanford MR: HLA and tumour necrosis factor (TNF) polymorphisms in ocular Behçet's disease. Tissue Antigens 1999, 54:264-272.

28. Mizuki N, Ota M, Katsuyama Y, Yabuki K, Ando H, Yoshida M, Onari K, Nikbin B, Davatchi F, Chams H, Ghaderi AA, Ohno S, Inoko H: HLA class I genotyping including HLA-B*51 allele typing in the Iranian patients with Behçet's disease. Tissue Antigens 2001, 57:457-462.

29. Kilmartin DJ, Finch A, Acheson RW: Primary association of HLA-B51 with Behçet's disease in Ireland. Br J Ophthalmol 1997, 81:649-653.

30. Kera J, Mizuki N, Ota M, Katsuyama Y, Pivetti-Pezzi P, Ohno S, Inoko H: Significant associations of HLA-B*5101 and B*5108, and lack of association of class II alleles with Behçet's disease in Italian patients. Tissue Antigens 1999, 54:565-571.

31. Pirim I, Atasoy M, Ikbal M, Erdem T, Aliagaoglu C: HLA class I and class II genotyping in patients with Behcet's disease: a regional study of eastern part of Turkey. Tissue Antigens 2004, 64:293-297.

32. Nakano H, Oka H, Matsuda T, Ooka S, Imamura Y, Suzuki T, Yamasaki Y, Itoh G, Azuma K, Ozaki S: Behçet's disease with vascular involvement: the contribution of anticardiolipin antibodies and thrombomodulin. Adv Exp Med Biol 2003, 528:395-398.

33. Kaburaki T, Takamoto M, Numaga J, Kawashima H, Araie M, Ohnogi $Y$, Harihara S, Kuwata S, Takeuchi F: Genetic association of HLA-A*2601 with ocular Behçet's disease in Japanese patients. Clin Exp Rheumatol 2010, 28 : S39-44.

\section{doi:10.1186/ar3292}

Cite this article as: Kang et al:: Associations between the HLA-A polymorphism and the clinical manifestations of Behcet's disease. Arthritis Research \& Therapy 2011 13:R49.

\section{Submit your next manuscript to BioMed Central and take full advantage of:}

- Convenient online submission

- Thorough peer review

- No space constraints or color figure charges

- Immediate publication on acceptance

- Inclusion in PubMed, CAS, Scopus and Google Scholar

- Research which is freely available for redistribution

Submit your manuscript at www.biomedcentral.com/submit
Ciomed Central 